Brit. J. industr. Med., 1956, 13, 177.

\title{
FACTORS INFLUENCING THE RADIOLOGICAL PROGRESSION RATE OF PROGRESSIVE MASSIVE FIBROSIS
}

\author{
BY \\ A. L. COCHRANE and R. G. CARPENTER \\ with the assistance of \\ W. G. CLARKE, G. JONATHAN, and F. MOORE \\ From the Pneumoconiosis Research Unit of the Medical Research Council, Llandough Hospital, near Cardiff
}

(RECEIVED FOR PUBLICATION JANUARY 1, 1956)

The Workmen's Compensation (Silicosis) Act (1918) empowered the Secretary of State to make (inter alia) schemes "for the payment of compensation to workmen who are found on medical examination to be suffering from silicosis or silicosis combined with tuberculosis to such a degree as to make it dangerous to continue work in the industry and are for that reason suspended from employment". The idea that when a certain stage of silicosis has been reached it becomes dangerous to continue at work appears to have its origin in the Miners' Phthisis Act (1912) in the Union of South Africa, but neither in 1912 nor in 1918 does there appear to have been any detailed discussion of the stage at which it became more dangerous to continue at work than to leave it: or, to put the problem in more epidemiological terms, the stage after which the progression rate, i.e., deterioration rate, was higher at work in the mines than outside.

Coal-mining was not included in the list of industries scheduled in the original scheme (Refractory Industries (Silicosis) Scheme, 1919) but was added in 1928 (Various Industries (Silicosis) Scheme). Even then, owing to the phrase " exposure to silica dust " in the Act, few coal-miners were certified until the Coal Mining Industry (Pneumoconiosis) Compensation Scheme (1943). After this date large numbers of coal-miners, particularly in South Wales, were "certified" and "suspended" from further work in the industry. There was at that time considerable evidence that coalworkers' pneumoconiosis was a different disease from "classical" silicosis, as described in South Africa, but, in the absence of any direct evidence about the progression rates inside and outside mining, it no doubt appeared safer to suspend miners with pneumoconiosis from the environment which appeared to have caused it.

Böhme (1933) appears to have been the first to point out that radiological progression did take place after exposure to dust had ceased amongst coal-miners with " silicosis". At first, it was uncertain whether the condition he was referring to was the same as that seen in South Wales, but the same phenomenon was soon observed in a short series by Aslett, Davies, and Jenkins (1943) and was later confirmed by Stewart, Davies, Dowsett, Morrell, and Pierce (1948). Later, after Davies and Mann (1949) had differentiated simple pneumoconiosis from progressive massive fibrosis (P.M.F.), Davies, Fletcher, Mann, and Stewart (1949), on a small series, showed that there was no significant difference between the frequency with which progression of P.M.F. was seen in the radiographs amongst those who left mining and those who continued to work as miners. (As " frequency of progression" is a somewhat clumsy phrase, "rate of progression" has been used throughout this paper.) It was against this somewhat uncertain background that the new regulations governing pneumoconiosis under the National Insurance (Industrial Injuries) Act, 1946, were introduced. These abolished the power of suspension (except in cases of infectious tuberculosis), and at present large numbers of miners with P.M.F., particularly in South Wales, are continuing at work in the mines. It is therefore of importance that further information should be obtained on this subject.

It is, however, not a simple matter to get definite information. The most satisfactory method would be to allocate at random miners with P.M.F. into 
two groups and arrange that one group continued mining and the other left mining, and to radiograph again both groups after two or three years. But this would be exceedingly difficult-if not impossible. One is therefore forced to be content with observing the cases as they " select" themselves into the two groups, and the possible biases associated with such self-selection are only too clear. The more disabled cases, for instance, will probably leave mining and seek lighter employment outside. Similarly, those who leave mining will, on the average, have a lower income, even when pensions are taken into account, and this might influence the progression rate independently of the dust exposure.

Deaths introduce further complications. Some of the deaths can be considered as the extreme form of progression; others, of course, are due to other causes. This would be unimportant if the two groups had been randomly allocated, but becomes important when one is relying on observation of self-selected groups. There is also the further difficulty that those dying of P.M.F. (and from all other causes except accidents and possibly some types of vascular disease) will tend to leave mining some time before death. Deaths thus tend to occur predominantly in the groups with " non-mining "or " mixed " occupations and not in the " mining" group.

The only solution to this problem appears to be the restriction of the observation to such an early type of P.M.F. that it is highly unlikely that it will be a cause of death during the planned period of observation. Fortunately we have evidence that death rates amongst those with " $A$ " shadows (the earliest stage of P.M.F.), standardized for age, in the 2.6 years following a survey are no higher than those for miners and ex-miners whose radiographs show no pneumoconiosis, while there is some evidence that those with " $\mathrm{B}$ ", " $\mathrm{C}$ ", and " $\mathrm{D}$ " shadows (the more advanced stages of P.M.F.) have a somewhat reduced life expectancy (Carpenter and Cochrane, 1956). The best approach would therefore appear to be to use as large and as complete a population of men with " $A$ " shadows as possible and follow them for a relatively short period, realiz- ing at the same time that any difference amongst those outside mining compared with those in mining may be due to self-selection.

The only previously published group approaching this description is that used by Miall, Oldham, and Cochrane (1954), when investigating the effect of isoniazid on the progression rate of P.M.F. They also analysed the effect of "dusty" and "nondusty" occupations. The difference was not significant but the size of the groups made the test somewhat insensitive. The trend suggested that there was a higher progression rate in the dusty group.

\section{Material}

Details of the first and second Rhondda Fach surveys have already been published (Cochrane, Cox, and Jarman, 1952, 1955). Ninety-five per cent. of the miners and ex-miners were radiographed on both occasions. This paper is concerned with those whose radiographs showed P.M.F. at the time of the first survey, and, in particular, with the differences between radiographs taken during the two surveys in 1950/51 and 1953. The material has been subdivided into those with " $\mathrm{A}$ " shadows at the time of the first survey and those with "B", "C", and " $D$ " shadows.

The pairs of radiographs were read, without any knowledge of the men's ages or industrial histories, by two pairs of readers, A. L. C. and Dr. Idris Davies, and Drs. S. Rae and P. J. Chapman. Each pair of readers classified the films separately. If there was any disagreement, an agreed reading was obtained with all four readers present. The films were classified-as far as P.M.F. is concerned-into "no change" and "definite progression". The industrial histories were obtained direct from the miners and ex-miners at the time of the two surveys. From the details obtained, they have been classified into " mining" (including surface work), " outside mining ", and " mining and outside" for the period between the two surveys.

\section{Results}

Table 1 shows details of the follow-up of the 364

TABLE 1

FOLLOW-UP OF MINERS AND EX-MINERS WITH PROGRESSIVE MASSIVE FIBROSIS (CATEGORY “A ") 1950/51 (SPUTUM POSITIVE AND NEGATIVE) RADIOGRAPHED AGAIN IN 1953

\begin{tabular}{|c|c|c|c|c|c|c|c|}
\hline $\begin{array}{c}\text { Age } \\
\text { Group }\end{array}$ & No. & $\begin{array}{l}\text { No. } \\
\text { Dead }\end{array}$ & $\begin{array}{l}\text { No. } \\
\text { Remaining }\end{array}$ & $\begin{array}{c}\text { No. Radiographed } \\
1953\end{array}$ & $\begin{array}{c}\% \\
\text { Radiographed }\end{array}$ & $\underset{1950 / 51}{\text { Sputum }}$ & $\begin{array}{l}\text { No. } \\
\text { Remaining }\end{array}$ \\
\hline $\begin{array}{l}15-24 \\
25-34 \\
35-44 \\
45-54 \\
55-64 \\
65+\end{array}$ & $\begin{array}{r}44 \\
45 \\
87 \\
90 \\
73 \\
65\end{array}$ & $\begin{array}{l}- \\
\overline{2} \\
2 \\
2 \\
7\end{array}$ & $\begin{array}{r}44 \\
45 \\
85 \\
88 \\
71 \\
58\end{array}$ & $\begin{array}{r}4 \\
45 \\
85 \\
88 \\
70 \\
50\end{array}$ & $\begin{array}{r}100.0 \\
100.0 \\
100.0 \\
100.0 \\
98.6 \\
86.2\end{array}$ & $\begin{array}{l}\overline{-} \\
1 \\
1 \\
-\end{array}$ & $\begin{array}{r}4 \\
45 \\
84 \\
87 \\
70 \\
50 \\
\end{array}$ \\
\hline Total & 364 & 13 & 351 & 342 & $97 \cdot 4$ & 2 & 340 \\
\hline
\end{tabular}


TABLE 2

RADIOLOGICAL PROGRESSION OF CATEGORY “A” SHADOWS IN SPUTUM-NEGATIVE CASES BETWEEN AGES OF 25 AND 64 ANALYSED BY OCCUPATION

\begin{tabular}{|c|c|c|c|c|c|c|c|c|c|}
\hline $\begin{array}{l}\text { Occupation } \\
\text { between } \\
\text { Surveys }\end{array}$ & Age & $\begin{array}{c}\text { No. } \\
\text { Radiographed } \\
1950 / 51\end{array}$ & $\begin{array}{l}\text { No. } \\
\text { Dead }\end{array}$ & $\begin{array}{c}\text { No. not } \\
\text { Radiographed } \\
1953\end{array}$ & $\begin{array}{c}\text { No. Sputum } \\
\text { Positive } \\
1950 / 51\end{array}$ & $\begin{array}{l}\text { No. } \\
\text { Remaining }\end{array}$ & $\begin{array}{c}\text { Definite } \\
\text { Progression }\end{array}$ & $\%$ & $\underset{\%}{\text { Overall }}$ \\
\hline In mining.. & $\begin{array}{l}25-34 \\
35-44 \\
45-54 \\
55-64\end{array}$ & $\begin{array}{l}17 \\
35 \\
34 \\
28\end{array}$ & $1(1)$ & & & $\begin{array}{l}17 \\
35 \\
33 \\
28\end{array}$ & $\begin{array}{r}8 \\
10 \\
8 \\
5\end{array}$ & $\begin{array}{l}47 \cdot 1 \\
28 \cdot 6 \\
24 \cdot 2 \\
17 \cdot 9\end{array}$ & $27 \cdot 4$ \\
\hline Outside mining & $\begin{array}{l}25-34 \\
35-44 \\
45-54 \\
55-64\end{array}$ & $\begin{array}{l}21 \\
40 \\
49 \\
43\end{array}$ & $\begin{array}{l}1(2) \\
2(3)(4)\end{array}$ & 1 & $\begin{array}{l}1 \\
1\end{array}$ & $\begin{array}{l}21 \\
38 \\
48 \\
40\end{array}$ & $\begin{array}{r}7 \\
10 \\
3 \\
5\end{array}$ & $\begin{array}{r}33 \cdot 3 \\
26 \cdot 3 \\
6 \cdot 3 \\
12 \cdot 5\end{array}$ & $17 \cdot 0$ \\
\hline Mining and outside & $\begin{array}{l}25-34 \\
35-44 \\
45-54 \\
55-64 \\
\end{array}$ & $\begin{array}{r}7 \\
10 \\
7 \\
2\end{array}$ & $\begin{array}{l}1(5) \\
1(6)\end{array}$ & & & $\begin{array}{l}7 \\
9 \\
6 \\
2\end{array}$ & $\begin{array}{l}1 \\
1 \\
2 \\
2\end{array}$ & $\begin{array}{r}14 \cdot 3 \\
11 \cdot 1 \\
33 \cdot 3 \\
100 \cdot 0\end{array}$ & $25 \cdot 0$ \\
\hline $\begin{array}{ccc}\text { Other dusty occupa- } \\
\text { tions } & . & \ldots \\
\end{array}$ & $35-44$ & 2 & & & & 2 & - & - & \\
\hline Total & $\overline{\text { All ages }}$ & 295 & 6 & 1 & 2 & 286 & 62 & $21 \cdot 7$ & \\
\hline
\end{tabular}

Causes of deaths : (1) Cardiac failure, coronary atheroma, and pulmonary infarction

(2) Coronary thrombosis, arterio-sclerosis, and hypertension. Diabetes

(3) Cerebral embolism, heart failure, hypertension

(4) Pneumonia, cancer of the liver

(5) Carcinoma of stomach, generalized secondary metastases

(6) Cachexia, carcinoma of stomach

miners and ex-miners whose radiographs were thought to have " A" shadows at the time of the first survey. At the time of the second survey, 2.6 years later, 13 of these were dead and nine refused to be radiographed, but only one of the latter was under 65. Two were found to have tubercle bacilli in their sputum at the time of the first survey.

For the analysis into those who continued mining and those who did not, we have discarded those under 25 because there are so few; we have also discarded those over 65 as they will be leaving mining in any case. We have also excluded the two cases with sputa positive for tubercle bacilli as there is no doubt about advising them to leave mining.

Table 2 gives the comparison between the progression rates by age in the three occupational groups. It should be noted that the deaths that occurred were not apparently related to chest disease. In Tables 3 and 4 and the figure the two main groups have been further subdivided and for the purpose of analysis " surface" and " other underground workers" (Table 3) have been grouped together, and those classified as " mixed " (Table 4) have been excluded as they were a heterogeneous small group.

In this way we have four groups of workers with men under and over the age of 45 in each. These 20-year age groups are very wide and slight variations of mean age occur between one group and the next within the same age group. Thus the mean age of men doing outdoor work in the age group 45 to 64 is 51 years while the mean age of the corresponding group doing indoor work is 56 years. This, however, is the largest difference of this type. But age is a significant factor which affects the percentage of men who progress. The analysis described below was therefore done using the actual age of the subjects, as in this way allowances for these minor variations may be made.

TABLE 3

FURTHER ANALYSIS OF MINERS BY TYPE OF OCCUPATION

\begin{tabular}{|c|c|c|c|c|c|c|c|c|c|}
\hline $\begin{array}{c}\text { Occupation } \\
\text { between } \\
\text { Surveys }\end{array}$ & Age & $\begin{array}{c}\text { No. } \\
\text { Radiographed } \\
1950 / 51\end{array}$ & $\begin{array}{l}\text { No. } \\
\text { Dead }\end{array}$ & $\begin{array}{c}\text { No. not } \\
\text { Radiographed } \\
1953\end{array}$ & $\begin{array}{l}\text { Sputum } \\
\text { Positive } \\
\text { 1950/51 }\end{array}$ & $\begin{array}{l}\text { No. } \\
\text { Remaining }\end{array}$ & $\begin{array}{c}\text { Definite } \\
\text { Progression }\end{array}$ & $\%$ & \\
\hline $\begin{array}{l}\text { Colliers and other face- } \\
\text { workers including } \\
\text { firemen } \\
\text { Other underground } \\
\text { workers } \\
\text { Surface workers }\end{array}$ & $\begin{array}{l}25-44 \\
45-64 \\
25-44 \\
45-64 \\
25-44 \\
45-64\end{array}$ & $\begin{array}{r}24 \\
6 \\
19 \\
41 \\
9 \\
15\end{array}$ & $1(1)$ & & & $\begin{array}{r}24 \\
6 \\
19 \\
40 \\
9 \\
15\end{array}$ & $\begin{array}{r}10 \\
2 \\
5 \\
8 \\
3 \\
3\end{array}$ & $\begin{array}{l}41 \cdot 7 \\
33 \cdot 3 \\
26 \cdot 3 \\
20 \cdot 0 \\
33 \cdot 3 \\
20 \cdot 0\end{array}$ & $\begin{array}{l}40 \cdot 0 \\
22 \cdot 0 \\
25 \cdot 0\end{array}$ \\
\hline Total $\quad$. & All ages & 114 & 1 & - & - & 113 & 31 & $27 \cdot 4$ & \\
\hline
\end{tabular}

For cause of death, see footnote to Table 2 
TABLE 4

FURTHER ANALYSIS OF THOSE WORKING OUTSIDE MINING BY TYPE OF OCCUPATION

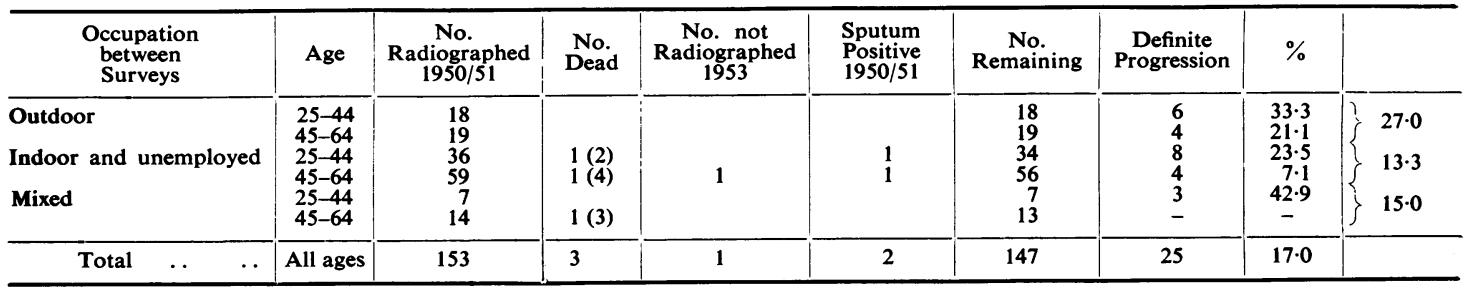

For causes of death, see footnote to Table 2

The first point is that the percentage progressing declines with age in each of the four groups of workers. This decline may be taken as $7 \cdot 3 \%$ $\pm 2.6 \%$ with every additional 10 years of life, within the age limits 25 to 64 . It should be noticed, however, that the number of our cases in the younger end of this age range is inevitably small.

This decline with age is significant. Hence the percentage progressing in the four groups of workers and the comparisons of the groups are given as though each group were the same age. This age is taken as the mean age of all the men, which is 46.7 years. This may be done since the decline in the percentage progressing with age is similar in each of the four occupational groups.

Table 5 summarizes the mean percentage progressing in the four occupational groups, adjusted for age, together with the standard errors of these

TABLE 5

PERCENTAGE OF MEN PROGRESSING IN DIFFERENT OCCUPATIONAL GROUPS WHEN AGE IS STANDARDIZED AT 46.7 YEARS

\begin{tabular}{|c|c|c|}
\hline Occupational Group & $\begin{array}{l}\text { Mean \% Progressing } \\
\text { Standardized for Age }\end{array}$ & $\begin{array}{l}\text { Standard Error } \\
\text { of Mean }(\%)\end{array}$ \\
\hline \multirow{2}{*}{$\begin{array}{l}\text { All mineworkers } \\
\text { Face workers ... } \\
\text { Other underground and } \\
\text { surface workers }\end{array}$} & $\begin{array}{l}26 \cdot 8 \\
35 \cdot 6\end{array}$ & $\begin{array}{l} \pm 3 \cdot 84 \\
\pm 7 \cdot 74\end{array}$ \\
\hline & $23 \cdot 8$ & \pm 4.49 \\
\hline \multirow{2}{*}{$\begin{array}{lc}\text { All outside mining } & \ldots \\
\text { Outdoor work } & \ldots \\
\text { Indoor work and unem- } \\
\text { ployed }\end{array}$} & $\begin{array}{l}17 \cdot 8 \\
25 \cdot 8\end{array}$ & $\begin{array}{l} \pm 3.62 \\
\pm 6.72\end{array}$ \\
\hline & $14 \cdot 4$ & $\pm 4 \cdot 32$ \\
\hline
\end{tabular}

TABLE 6

COMPARISONS OF MEAN PERCENTAGE PROGRESSING IN DIFFERENT OCCUPATIONAL GROUPS STANDARDIZED FOR AGE

\begin{tabular}{l|c|c|c}
\hline \multicolumn{1}{c|}{ Comparisons } & $\begin{array}{c}\text { Difference } \\
\text { of Mean } \\
\text { Percentages }\end{array}$ & $\begin{array}{c}\text { Standard } \\
\text { Error of } \\
\text { Difference (\%) }\end{array}$ & $\begin{array}{c}\text { Significance } \\
\text { of } \\
\text { Difference }\end{array}$ \\
\hline $\begin{array}{l}\text { Mineworkers- } \\
\text { non-miners }\end{array}$ & 9.0 & \pm 5.28 & $0.1>\mathbf{P}>0.05$ \\
$\begin{array}{l}\text { Faceworkers- } \\
\text { other mineworkers }\end{array}$ & 11.8 & \pm 9.06 & $0.3>\mathbf{P}>0.2$ \\
$\begin{array}{l}\text { Outdoor-indoor } \\
\text { Faceworkers- }\end{array}$ & 11.4 & \pm 8.03 & $\mathbf{0 . 2}>\mathbf{P}>0.1$ \\
indoor workers .. & 21.2 & \pm 9.01 & $\mathbf{P}=0.02$ \\
\hline
\end{tabular}

means. Table 6 compares the percentage progressing in the different groups. The difference of $9 \%$ between all the miners compared with all those working outside the mines is suggestive but not quite significant. The differences between faceworkers and other mineworkers and outdoor workers and indoor workers are not significant. It will, however, be noticed that contrary to previous findings our outdoor workers showed more progression than did indoor workers, which we attribute to the heavy work the latter were doing.

The difference between faceworkers and indoor workers is $21 \%$. This difference, which on a " $t$ " test has a probability of occurring by pure chance of 0.02 , is almost certainly real, even though it is the most extreme comparison that could have been made.

The analysis of the " B", " $\mathrm{C}$ ", and " $\mathrm{D}$ " shadows gives a different picture. Table 7 shows the

TABLE 7

FOLLOW-UP OF MINERS AND EX-MINERS WITH PROGRESSIVE MASSIVE FIBROSIS (CATEGORIES “ B ", “C ", AND “ D ”) 1950/51 (SPUTUM POSITIVE AND NEGATIVE)

\begin{tabular}{|c|c|c|c|c|c|c|c|}
\hline Age & No. & $\begin{array}{l}\text { No. } \\
\text { Dead }\end{array}$ & $\begin{array}{l}\text { No. } \\
\text { Remaining }\end{array}$ & No. Radiographed & $\%$ & $\underset{1950 / 51}{\text { Sputum }}$ Positive & $\begin{array}{c}\text { No. } \\
\text { Remaining }\end{array}$ \\
\hline $\begin{array}{l}15-24 \\
25-34 \\
35-44 \\
45-54 \\
55-64 \\
65+\end{array}$ & $\begin{array}{r}1 \\
25 \\
121 \\
137 \\
176 \\
161\end{array}$ & $\begin{array}{r}- \\
\overline{3} \\
5 \\
14 \\
37\end{array}$ & $\begin{array}{r}1 \\
25 \\
118 \\
132 \\
162 \\
124\end{array}$ & $\begin{array}{r}1 \\
22 \\
115 \\
120 \\
150 \\
109\end{array}$ & $\begin{array}{r}100.0 \\
88.0 \\
97.5 \\
90.9 \\
92.6 \\
87.9\end{array}$ & $\begin{array}{l}\overline{2} \\
2 \\
3 \\
2 \\
-\end{array}$ & $\begin{array}{r}1 \\
20 \\
113 \\
117 \\
148 \\
109\end{array}$ \\
\hline Total & 621 & 59 & 562 & 517 & $92 \cdot 0$ & 9 & 508 \\
\hline
\end{tabular}


TABLE 8

RADIOLOGICAL PROGRESSION OF CATEGORIES “B” “ C", AND “D” SHADOWS IN SPUTUM-NEGATIVE CASES BETWEEN THE AGES OF 25 AND 64 ANALYSED BY OCCUPATION

\begin{tabular}{|c|c|c|c|c|c|c|c|c|c|}
\hline $\begin{array}{c}\text { Occupation } \\
\text { between } \\
\text { Surveys }\end{array}$ & Age & $\begin{array}{c}\text { No. } \\
\text { Radiographed } \\
1950 / 51\end{array}$ & $\begin{array}{l}\text { No. } \\
\text { Dead }\end{array}$ & $\begin{array}{c}\text { No. not } \\
\text { Radiographed } \\
1953\end{array}$ & $\begin{array}{l}\text { No. Sputum } \\
\text { Positive } \\
1950 / 51\end{array}$ & $\begin{array}{c}\text { No. } \\
\text { Remaining }\end{array}$ & $\begin{array}{c}\text { Definite } \\
\text { Progression }\end{array}$ & $\%$ & $\underset{\%}{\text { Overall }}$ \\
\hline In mining & $\begin{array}{l}25-34 \\
35-44 \\
45-54 \\
55-64\end{array}$ & $\begin{array}{r}3 \\
19 \\
27 \\
27\end{array}$ & $\overline{-}$ & $\begin{array}{l}- \\
\overline{1} \\
-\end{array}$ & $\begin{array}{l}- \\
- \\
- \\
-\end{array}$ & $\begin{array}{r}3 \\
19 \\
25 \\
27\end{array}$ & $\begin{array}{r}1 \\
10 \\
9 \\
6\end{array}$ & $\begin{array}{l}33 \cdot 3 \\
52 \cdot 6 \\
36 \cdot 0 \\
22 \cdot 2\end{array}$ & $35 \cdot 1$ \\
\hline Outside mining & $\begin{array}{l}25-34 \\
35-44 \\
45-54 \\
55-64\end{array}$ & $\begin{array}{r}22 \\
97 \\
101 \\
146\end{array}$ & $\begin{array}{r}\overline{3} \\
4 \\
14\end{array}$ & $\begin{array}{r}3 \\
3 \\
11 \\
12\end{array}$ & $\begin{array}{l}2 \\
2 \\
3 \\
2\end{array}$ & $\begin{array}{r}17 \\
89 \\
83 \\
118\end{array}$ & $\begin{array}{r}6 \\
35 \\
32 \\
26\end{array}$ & $\begin{array}{l}35 \cdot 3 \\
39 \cdot 3 \\
38 \cdot 6 \\
22 \cdot 0\end{array}$ & $32 \cdot 2$ \\
\hline Mining and outside & $\begin{array}{l}25-34 \\
35-44 \\
45-54 \\
55-64\end{array}$ & $\begin{array}{r}- \\
5 \\
9 \\
3\end{array}$ & $\begin{array}{l}- \\
- \\
-\end{array}$ & $\begin{array}{l}- \\
- \\
-\end{array}$ & $\begin{array}{l}- \\
- \\
-\end{array}$ & $\begin{array}{l}\overline{5} \\
9 \\
3\end{array}$ & $\begin{array}{l}\overline{3} \\
4 \\
-\end{array}$ & $\begin{array}{l}60 \cdot 0 \\
44 \cdot 4 \\
-\end{array}$ & $41 \cdot 2$ \\
\hline Total $\ldots$ & $25-64$ & 459 & 22 & 30 & 9 & 398 & 132 & - & $33 \cdot 2$ \\
\hline
\end{tabular}

extent of the follow-up and Table 8 the division into those who left mining and those who continued in mining. It will be observed that although the progression rates in the two groups are similar there is every possibility of a bias having been

Fig. 1.-Factors influencing the radiological progression rate of progressive fibrosis (radiological category "A ").

\section{OCCUPATION}

TYPE OF WORK

AGE introduced either by the large number of lapses or by the deaths in the non-mining group, and that it would therefore be unwise to deduce anything from this.

\section{PERCENTAGE} PROGRESSING
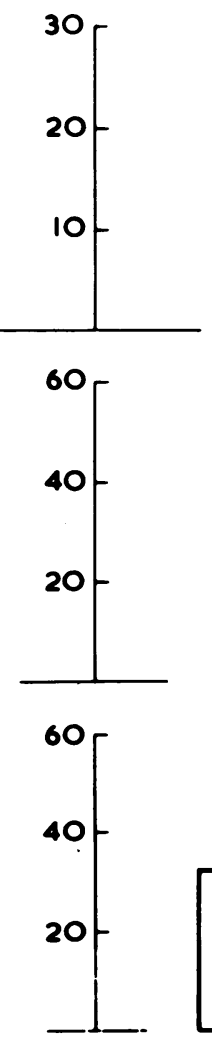


\section{Discussion}

This study has confirmed the fact noted by many observers that P.M.F. progresses after leaving mining. We have not been so successful in our attempt to confirm the work of Davies et al. (1949) which suggested that the rate of progression was the same whether the miner left mining or not. Our results have shown that, in addition to progression being influenced by age (the younger men having the higher rate), it is very probably influenced by working in the mines and by doing heavy work whether in mining or not. The importance of the last two factors cannot be considered as finally established but they are the factors that would be the easiest to control. Future research may show significant differences where ours are only suggestive, and it may seem reasonable to suggest that dust exposure is the effective agent in mining life. It should, however, be remembered that dust exposure is highly correlated with hard work in mining and that it is probable that hard work and light work in mining are harder than their corresponding processes outside mining. For the moment it would appear that the hypothesis that " hard " work is the effective factor must be accepted as the simplest explanation, although the effect of dust exposure cannot be excluded. As our groups were self-selected (as also were those of Davies) the probable direction of the bias introduced by the self-selection becomes of great importance. Most medical observers agree that the less fit, in general, tend to leave mining, and they might well be expected to be the more rapid progressors. If this is so-it must be stressed that this is a matter of opinion and not of fact-then our findings would be more significant as the excess of progressions would have been achieved against the bias.

The point at issue is an important one and clearly needs further investigation. There are two possible lines of approach: (i) A longer follow-up of the present series; this would certainly increase the number of progressors but would run into trouble from the point of view of lapses, and would not solve the problem of self-selection. (ii) A properly controlled trial with random allocation of miners into " mining" and "non-mining" groups; this presents enormous practical difficulties, but it could be attempted if the problem is considered sufficiently important.

As regards the immediate practical effects of our findings, two points can be made. As the rate of progression of P.M.F. decreases with age, we have an additional argument for postponing the attainment of category 2 , simple pneumoconiosis, as long as possible amongst coal-miners (if we cannot prevent it altogether), for at that stage the miner becomes increasingly at risk to the development of P.M.F. As regards the advice to be given to miners with "A" shadows, the situation is not very much clearer. The facts should be explained to them and all psychological and economic factors taken into account. But it now seems reasonable to bring some pressure to bear on young men with "A" shadows to leave the coal face and, if possible, re-train for some light indoor job.

\section{Summary}

The new regulations governing pneumoconiosis under the National Insurance (Industrial Injuries) Act (1946) abolished the power of suspension of miners (except those with infectious tuberculosis), and large numbers of miners with progressive massive fibrosis (P.M.F.) continue to work in the mines.

It is therefore of importance to determine the effects of occupation on the radiological progression rate of cases of massive fibrosis. The theoretical and practical difficulties of such an investigation are discussed.

Of 364 miners and ex-miners whose radiographs showed the earliest stage of P.M.F. at the time of the first Rhondda Fach Survey (1950/51), 342 were radiographed again in 1953.

An analysis by age and occupation of these cases suggests that three factors-age, mining, and hard work-are likely to affect the progression rate.

(a) With age there is a significant decline in the percentage progressing in all these men. This has a value of $7.3 \% \pm 2.6 \%$ for every additional 10 years of life within the age limits 25-64 years.

(b) All mineworkers showed a 9\% excess of progression over those who had left mining; this difference is suggestive but not statistically significant. The differences between coal-face workers and other mineworkers, and outdoor workers and indoor workers were not significant.

(c) The coal-face workers showed a significant excess of $21 \%$ progression over men employed in light indoor work.

It is therefore reasonable to advise young miners with early P.M.F. to leave the coal face and re-train in some more sedentary occupation.

This work was carried out under the general direction of the Rhondda Fach Scheme Advisory Committee and we should like to express our thanks to them for their help, encouragement, and advice. They are not in any way responsible, however, for the views expressed by the authors in this paper.

We should particularly like to thank the other members of the epidemiological team at the Pneumoconiosis Research Unit, who played a major part in both surveys; 
Dr. T. F. Jarman and his M.M.R. team who worked with us during the two surveys; the two field research teams of the National Coal Board under Dr. P. J. Chapman and Dr. S. Rae who worked with us during the second survey; Dr. C. M. Fletcher, previously Director of the Unit; Dr. J. C. Gilson, the Director; Dr. Idris Davies, Dr. W. E. Miall, and Mr. P. D. Oldham, members of the scientific staff of the Pneumoconiosis Research Unit; the numerous officials of the National Coal Board and the National Union of Mineworkers who assisted us in the surveys; the Cardiff Pneumoconiosis Medical Panel of the Ministry of Pensions and National Insurance and many others who lent us films; the Medical Officer of Health, Rhondda Urban District, and his department; and above all, the miners and ex- miners of the Rhondda Fach without whose help this work would have been impossible.

\section{REFERENCES}

Aslett, E. A., Davies, T. W., and Jenkins, T. I. (1943). Brit. J. Radiol, 16, 308.

Böhme, A. (1933). Beitr. Klin. Tuberk., 84, 119.

Carpenter, R. G., and Cochrane, A. L. (1956). British Journal of Industrial Medicine, 13, 102.

Cochrane, A. L., Cox, J. G., and Jarman, T. F. (1952). Brit. med. J., $2,843$.

$\overline{D a v i e s,}$, and- (1955). Ibid., 1, 371. Proc. 9th Int. Congr. on Industr. Med., London, 1948, p. 773. Wright, Bristol.

Med., 1948. London, p. 769.

Miall, W. E., Oldham, P. D., and Cochrane, A. L. (1954). British Journal of Industrial Medicine, 11, 186.

Stewart, A., Davies, I., Dowsett, L., Morrell, F. H., and Pierce, J. W. 